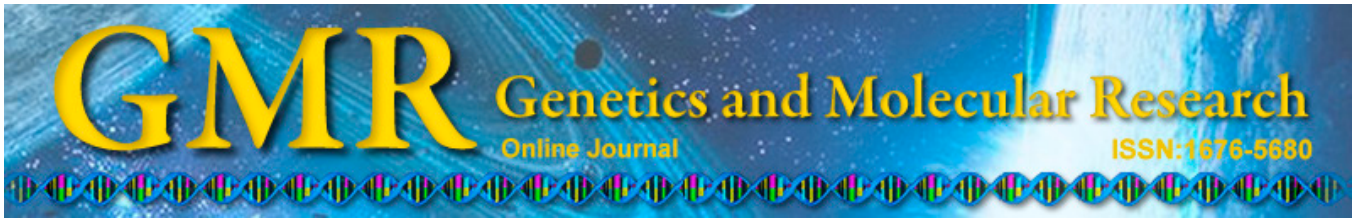

\title{
Polymorphisms in the bovine $C I D E C$ gene are associated with body measurement traits and meat quality traits in Qinchuan cattle
}

\author{
C.G. Mei ${ }^{1}$, L.S. Gui ${ }^{1}$, C.Z. Fu ${ }^{1}$, H.C. Wang ${ }^{1}$, J.L. Wang ${ }^{1}$, \\ G. Cheng ${ }^{1,2}$ and L.S. Zan ${ }^{1,2}$ \\ ${ }^{1}$ College of Animal Science and Technology, Northwest A\&F University, \\ Yangling, Shaanxi, China \\ ${ }^{2}$ National Beef Cattle Improvement Center of Northwest A\&F University, \\ Yangling, Shaanxi, China \\ Corresponding author: L.S. Zan \\ E-mail: zanlinsen@163.com
}

Genet. Mol. Res. 14 (3): 9013-9023 (2015)

Received December 18, 2014

Accepted May 28, 2015

Published August 7, 2015

DOI http://dx.doi.org/10.4238/2015.August.7.10

\begin{abstract}
Previous studies have shown that the cell death-inducing DFF45-like effector-C (CIDEC) gene is involved in lipid storage and energy metabolism, suggesting that it is a potential candidate gene that affects body measurement traits (BMTs) and meat quality traits (MQTs). The aim of this study was to identify polymorphisms of the bovine CIDEC gene and analyze their possible associations with BMTs and MQTs in 531 randomly selected Qinchuan cattle aged between 18 and 24 months. DNA sequencing and polymerase chain reaction-restriction fragment length polymorphism were employed to detect $C I D E C$ single nucleotide polymorphisms (SNPs). We found five SNPs: two in exon 5 (SNP1, g.9815G $>$ A and SNP2, g.9924C $>$ T) and three in the 3'-untranslated region (SNP3, g.13281C $>$ T; SNP4, g.13297A $>$ G; and SNP5, g.13307G $>$ A). SNP1 was a missense mutation that resulted in an arginine to glutamine amino acid change, and exhibited two genotypes (GG and AG). SNP2 was a synonymous mutation that exhibited three
\end{abstract}


genotypes (CC, CT, and TT). SNP3, 4, and 5 were completely linked, and only exhibited two genotypes (CC-AA-GG and CT-AG-GA). We found significant associations between these polymorphisms and BMTs and MQTs $(\mathrm{P}<0.05)$; GG, CT, and CT-AG-GA appeared to be the most beneficial genotypes. Therefore, CIDEC may affect BMTs and MQTs in Qinchuan cattle, and could be used in marker-assisted selection.

Key words: $C I D E C$; Single nucleotide polymorphism; Body measurement trait; Meat quality trait; Qinchuan cattle

\section{INTRODUCTION}

The identification of genetic markers that are positively associated with important economic traits in livestock species, such as body measurement traits (BMTs) and meat quality traits (MQTs), has the potential to significantly alter the rate of genetic improvement through the use of marker-assisted selection (MAS) (Nkrumah et al., 2004).

Beef is a nutrient-rich food, and contains high-quality protein, vitamin B, niacin, zinc, and iron. Qinchuan are yellow cattle that are indigenous to China, and exhibit a slow growth rate and an underdeveloped hind hip. It is necessary to identify important functional bovine genes by MAS, in order to accelerate the efficiency of Chinese beef cattle breeding.

Cell death-inducing DFF45-like effector-C (CIDEC) belongs to the CIDE family, which includes CIDEA, CIDEB, and CIDEC/Fsp27 (Inohara et al., 1998), and is a homolog of rodent $F s p 27$ (Fat-specific protein 27), which is associated with lipid and energy metabolism as well as obesity and obesity-related metabolic disturbances, such as insulin resistance and type 2 diabetes mellitus (Liang et al., 2003; Puri et al., 2007; Keller et al., 2008; Nishino et al., 2008; Toh et al., 2008). Peroxisome proliferator activated receptor- $\gamma(P P A R \gamma)$ and CCAAT/ enhancer-binding protein are considered to be key in regulating the transcription of Fsp27 (Danesch et al., 1992). Similarly, CIDEC is predominantly expressed in adipose tissue, but has also been detected in the small intestine, heart, colon, and stomach, suggesting that $C I D E C$ is not adipose tissue-specific (Liang et al., 2003; Magnusson et al., 2008). CIDEC allows adipocytes to adjust their metabolisms according to changes in whole-body energy availability, and facilitates lipid storage during periods of energy surplus (Magnusson et al., 2008). Li et al. (2010) suggested that $C I D E C$ is essential for the formation and maturation of lipid droplets in adipocytes, and the regulation of adipocyte lipid metabolism. Recent studies have revealed that PPAR $\mathrm{y}$ is an important regulator of the transcriptional activity of CIDEC during adipogenesis (Kim et al., 2008).

In 2009, a female patient was found to be homozygous for a single nucleotide polymorphism (SNP) involving a $\mathrm{G}$ to $\mathrm{T}$ transversion in $C I D E C$ exon 6, which caused a Glu $186 \mathrm{X}$ nonsense mutation in the CIDE-C domain that has been identified as an autosomal recessive form of familial partial lipodystrophy (Rubio-Cabezas et al., 2009). In addition, it is noteworthy that $C I D E C$ hepatic expression levels positively correlate with the body mass index (Hall et al., 2010).

Considering the importance of CIDEC in energy and lipid metabolism, as well as in metabolic disorders, it may be an attractive candidate gene for BMTs and MQTs in cattle. Therefore, in this study we aimed to detect polymorphisms in the bovine CIDEC gene, and evaluate their associations with BMTs and MQTs in Qinchuan cattle. The results of this study further our knowledge of the functions of $C I D E C$, and are useful for future studies into this topic. 


\section{MATERIAL AND METHODS}

\section{DNA samples and data collection}

Blood samples from 531 randomly selected individuals aged between 18 and 24 months from a breeding Qinchuan cattle population were used to analyze CIDEC allelic frequencies. BMTs were measured as previously described (Gilbert et al., 1993), including body length (BL), withers height (WH), hip height (HH), rump length (RL), hip width (HW), chest depth (CD), heart girth (HG), and pin bone width (PBW). Ultrasound backfat thickness (UBT) and ultrasound loin muscle area (ULA) were measured to evaluate MQTs (Brethour, 1994; Hamlin et al., 1995). A single person was appointed to measure each of the ten traits, in order to minimize systematic error.

Genomic DNA samples were extracted from the blood samples using a standard phenol-chloroform method (Müllenbach et al., 1989), and subsequently stored at $-80^{\circ} \mathrm{C}$.

\section{Polymerase chain reaction (PCR) and DNA sequencing}

Based upon the bovine CIDEC gene sequence (AC_000179), primers were designed to amplify fragments of CIDEC exon 5 and the 3'-untranslated region (UTR) using the PRIMER 5 software (Table 1). PCR amplifications were performed in a $20-\mu \mathrm{L}$ reaction mixture containing $50 \mathrm{ng}$ DNA, the primers (10 pM each), $0.20 \mathrm{mM} \mathrm{dNTPs,} 2.5 \mathrm{mM} \mathrm{MgCl}$, and $0.5 \mathrm{U}$ Taq DNA polymerase (TaKaRa, Dalian, China). The PCR protocol was as follows: $95^{\circ} \mathrm{C}$ for $5 \mathrm{~min}, 35$ cycles of denaturing at $94^{\circ} \mathrm{C}$ for $30 \mathrm{~s}$, annealing at $\mathrm{Tm}{ }^{\circ} \mathrm{C}$ (Table 1) for 30 $\mathrm{s}$, and extension at $72^{\circ} \mathrm{C}$ for $30 \mathrm{~s}$, with a final extension at $72^{\circ} \mathrm{C}$ for $10 \mathrm{~min}$. The products for sequencing were first electrophoresed on $1.5 \%$ agarose gels (containing $200 \mathrm{ng} / \mathrm{mL}$ ethidium bromide), and then purified using an Axygen ${ }^{\mathrm{TM}}$ kit (BMI Fermentas, Glen Burnie, MD, USA), and sequenced in both directions in an ABI PRIZM 377 DNA sequencer (Perkin-Elmer). The DNASTAR software package was used to analyze the sequence maps.

\begin{tabular}{|c|c|c|c|c|}
\hline Amplified region & & Primer & $\operatorname{Tm}\left({ }^{\circ} \mathrm{C}\right)$ & Size (bp) \\
\hline Exon 5 & Primer A & $\begin{array}{l}\text { F: 5'-TGGCAGCCCCCATCAGAAC-3' } \\
\text { R: 5'-GTATCCAGATTCCACCAGCAG-3' }\end{array}$ & 64.2 & 516 \\
\hline 3'-UTR & Primer B & $\begin{array}{l}\text { F: 5'-GCAGGCATTTAGAAGAGGC-3' } \\
\text { R: 5'-TGAGGGAGATGTAGGAAGGT-3' }\end{array}$ & 57.7 & 332 \\
\hline
\end{tabular}

$\mathrm{Tm}=$ melting temperature.

\section{Genotyping CIDEC alleles by PCR-restriction fragment length polymorphism (PCR-RFLP)}

Five novel SNPs were found in the bovine $C I D E C$ gene by DNA sequencing, two in exon 5 (SNP1, g.9815G $>$ A, Figure 1A and B; and SNP2, g.9924C $>$ T, Figure 2A, B, and C) and three in the 3'-UTR (SNP3, g.13281C>T; SNP4, g.13297A >G; and SNP5, g.13307G $>$ A; Figure $3 \mathrm{~A}$ and B). It is worth noting that SNP3, 4, and 5 were completely linked (data not shown). 
Finally, SNP1, 2, and 5 were chosen for further genotype detection by RFLP; aliquots $(10 \mu \mathrm{L})$ of the PCR products were digested with $10 \mathrm{U}$ Eco88I, MspI, and MspI, respectively (TaKaRa) at $37^{\circ} \mathrm{C}$ for $16 \mathrm{~h}$, following the instructions provided in the supplier's manual. The digested products were detected by electrophoresis on a $1.5 \%$ agarose gel stained with ethidium bromide.

\section{Statistical analysis}

Genotypic frequencies, allelic frequencies, Hardy-Weinberg equilibrium, gene homozygosity, gene heterozygosity, effective allele numbers, and the polymorphism information content (PIC) were statistically analyzed according to previous studies (Nei and Roychoudhury, 1974; Nei and Li, 1979). Associations between the SNP-marker genotypes of CIDEC and body measurement and meat quality traits (BL, WH, HH, RL, HW, CD, HG, PBW, UBT, and ULA) were analyzed using the SPSS software (version17.0), according to the following linear model:

$$
\mathrm{Y}_{\mathrm{ijk}}=\mu+\mathrm{G}_{\mathrm{i}}+\mathrm{A}_{\mathrm{j}}+\varepsilon_{\mathrm{ijk}}
$$

where $Y_{i j k}$ is the measurement of the trait, $\mu$ is the overall mean for each trait, $G_{i}$ is the genotype effect, $A_{j}$ is the fixed effect of age, and $\varepsilon_{i j k}$ is the random error.

\section{RESULTS}

\section{Genetic polymorphisms of $C I D E C$ and chi-square test}

As previously described in this paper (see Material and Methods), five SNPs were detected in the bovine CIDEC gene. At the SNP1 site, which resulted in a missense mutation of arginine to glutamine, two genotypes were present, namely GG and AG (Figure 1A and B). SNP2 was a synonymous mutation with three genotypes, namely CC, CT, and TT (Figure 2A, $\mathrm{B}$, and C). SNP3, 4, and 5 were completely linked and had two genotypes, namely CC-AA-GG and CT-AG-GA (Figure 3A and B).

A

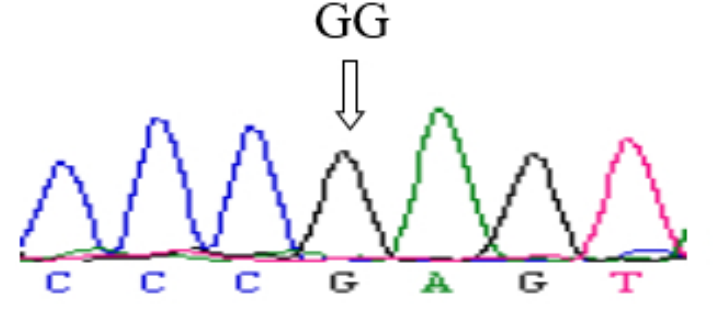

B

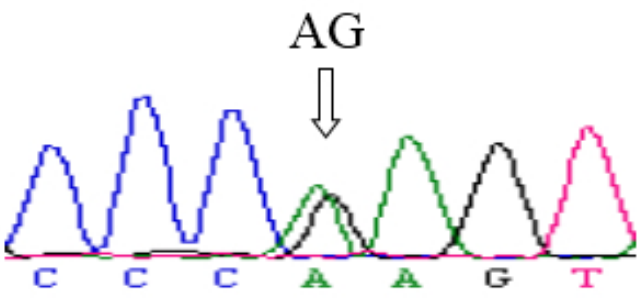

Figure 1. A. and B. Sequencing map of SNP1 in the bovine CIDEC gene exon 5 (9815-bp locus). 
A

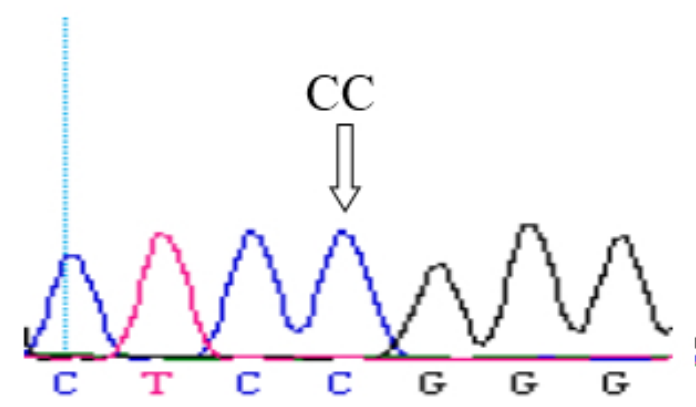

C

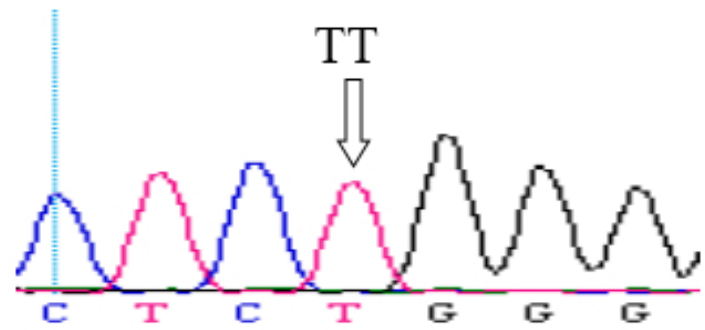

Figure 2. A.-C. Sequencing map of SNP2 in the bovine CIDEC gene exon 5 (9924-bp locus).

A

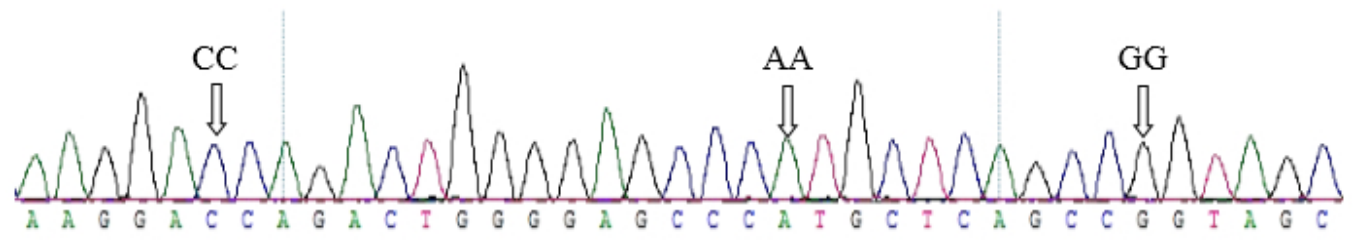

B

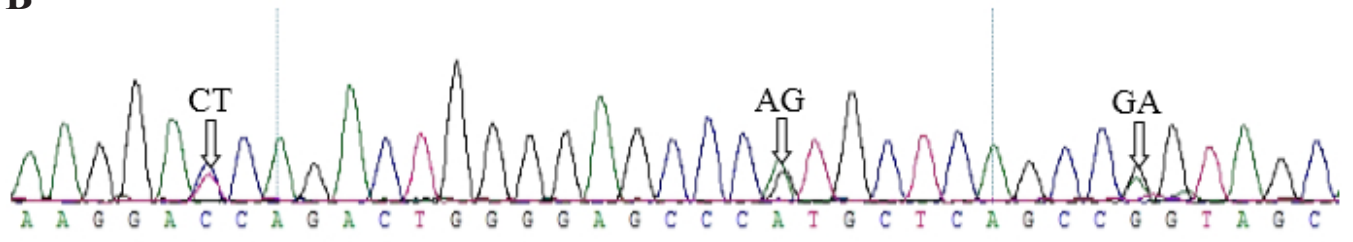

Figure 3. A. and B. Sequencing map of SNP3-SNP4-SNP5 in the bovine CIDEC gene 3'-untranslated region (13281-, 13297-, and 13307-bp locus). 
The products of Primer A were digested with Eco88I endonuclease to genotype SNP1, and the electrophoretic pattern obtained revealed two fragments (358 and $158 \mathrm{bp}$ ) for genotype GG and three fragments $(516,358$, and $158 \mathrm{bp}$ ) for the heterozygote AG (Figure 4). SNP2 was genotyped by the $M s p I$ endonuclease, and the resulting electrophoretic pattern revealed two fragments (267 and $247 \mathrm{bp}$ ) for genotype CC, three fragments $(516,267$, and $247 \mathrm{bp}$ ) for CT, and one 516-bp fragment for TT (Figure 5). It should be pointed out that the difference between the 267- and 247-bp fragment lengths was extremely small; consequently, they were difficult to separate, but this did not affect the identification of the genotypes of this SNP. The 332-bp products of Primer B were digested with Msp I to genotype SNP3SNP4-SNP5, which revealed two fragments (274 and $58 \mathrm{bp}$ ) for genotype CC-AA-GG and three $(332,274$, and $58 \mathrm{bp}$ ) for CT-AG-GA (Figure 6).

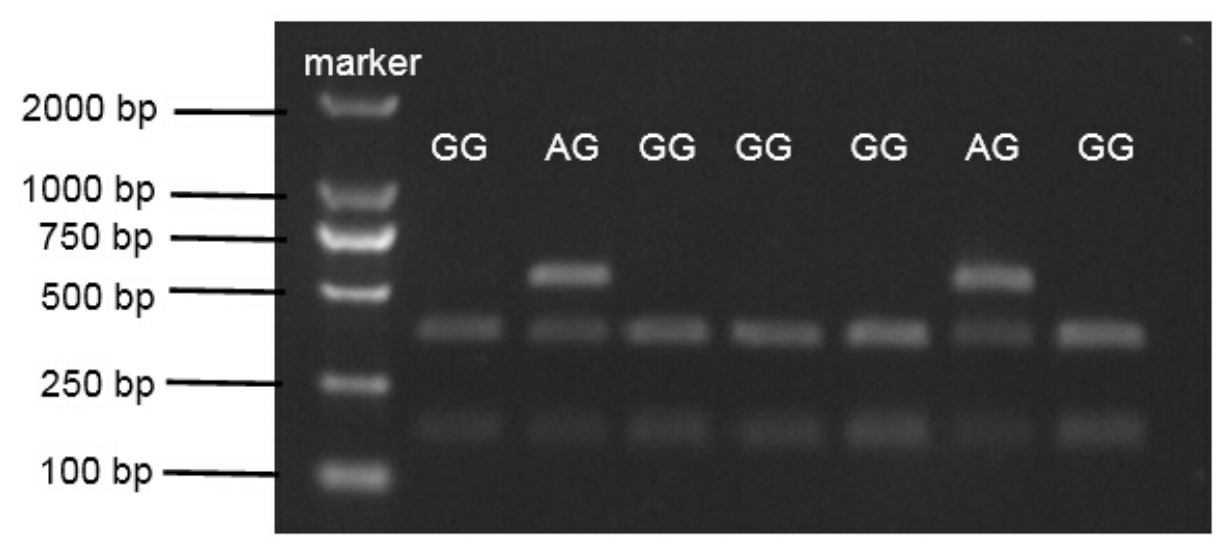

Figure 4. Polymerase chain reaction-restriction fragment length polymorphism electrophoresis patterns of the bovine CIDEC gene exon 5 (9815-bp locus).

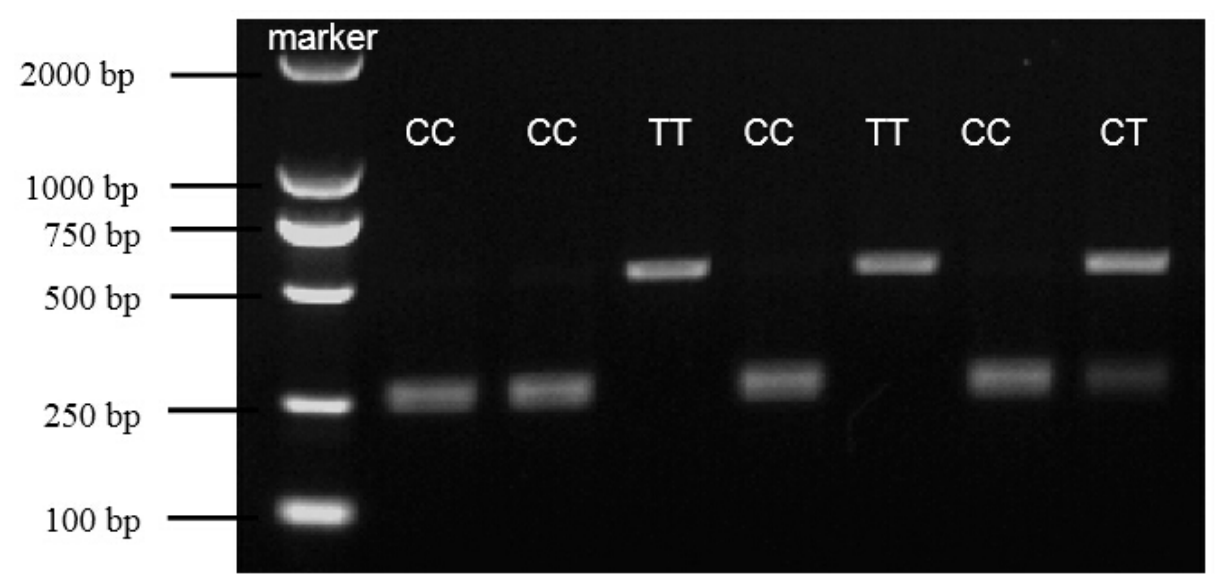

Figure 5. Polymerase chain reaction-restriction fragment length polymorphism electrophoresis patterns of the bovine CIDEC gene exon 5 (9924-bp locus). 




Figure 6. Polymerase chain reaction-restriction fragment length polymorphism electrophoresis patterns of the bovine CIDEC gene 3'-UTR (13307-bp locus).

The genetic diversity and population genetic characteristics of each locus are presented in Tables 2 and 3. A chi-square test indicated that the genotype distributions of SNP2 and SNP3-SNP4-SNP5 were in Hardy-Weinberg equilibrium $\left(\chi^{2}<\chi_{0.05}{ }^{2}\right)$, except for the SNP1 mutation $\left(\chi_{0.05}^{2}<\chi^{2}<\chi_{0.01}^{2}\right)$. According to the PIC, the experimental Qinchuan cattle population exhibited a medium level of polymorphism at SNP2 and low levels of polymorphism at SNP1 and SNP3-SNP4-SNP5.

Table 2. Genotypic and allelic frequencies (\%) of CIDEC gene single nucleotide polymorphisms (SNPs) in Qinchuan cattle.

\begin{tabular}{|c|c|c|c|c|c|}
\hline \multirow[t]{2}{*}{ SNP } & \multirow[t]{2}{*}{ Observed genotype (number) } & \multirow[t]{2}{*}{ Total } & \multicolumn{2}{|c|}{ Frequency } & \multirow[t]{2}{*}{$\chi^{2}(\mathrm{HWE})$} \\
\hline & & & Genotype & Allele & \\
\hline SNP1 & $\begin{array}{l}\mathrm{GG}(\mathrm{N}=423) \\
\mathrm{AG}(\mathrm{N}=108)\end{array}$ & 531 & $\begin{array}{l}0.7966 \\
0.2034\end{array}$ & $\begin{aligned} G & =0.8983 \\
A & =0.1017\end{aligned}$ & 6.8053 \\
\hline SNP2 & $\begin{array}{l}\mathrm{CC}(\mathrm{N}=282) \\
\mathrm{CT}(\mathrm{N}=204) \\
\text { TT }(\mathrm{N}=45)\end{array}$ & 531 & $\begin{array}{l}0.5311 \\
0.3842 \\
0.0847\end{array}$ & $\begin{array}{l}\mathrm{C}=0.7232 \\
\mathrm{~T}=0.2768\end{array}$ & 0.8709 \\
\hline SNP3-SNP4-SNP5 & $\begin{array}{l}\text { CC-AA-GG }(\mathrm{N}=466) \\
\text { CT-AG-GA }(\mathrm{N}=65)\end{array}$ & 531 & $\begin{array}{l}0.8776 \\
0.1224\end{array}$ & $\begin{aligned} \mathrm{C}-\mathrm{A}-\mathrm{G} & =0.9388 \\
\mathrm{~T}-\mathrm{G}-\mathrm{A} & =0.0612\end{aligned}$ & 2.2570 \\
\hline
\end{tabular}

HWE $=$ Hardy-Weinberg equilibrium; $\chi_{0.05}^{2}=5.991, \chi_{0.01}^{2}=9.21$.

Table 3. Population genetic characteristics of CIDEC gene single nucleotide polymorphisms (SNPs) in Qinchuan cattle.

\begin{tabular}{lcccc}
\hline SNP & Gene homozygosity & Gene heterozygosity & Effective allele number & $\begin{array}{c}\text { Polymorphism information } \\
\text { content (PIC) }\end{array}$ \\
\hline SNP1 & 0.8173 & 0.1827 & 1.2236 & 0.1660 \\
SNP2 & 0.5996 & 0.4004 & 1.6678 & 0.3202 \\
SNP3-SNP4-SNP5 & 0.8851 & 0.1149 & 1.1298 & 0.1083 \\
\hline
\end{tabular}

PIC $>0.5$ indicates a high level of polymorphism, $0.25<$ PIC $<0.5$ indicates a moderate level of polymorphism, and PIC $<0.25$ indicates a low level of polymorphism. 


\section{Associations between polymorphisms and BMTs and MQTs}

Associations between the CIDEC polymorphisms and eight BMTs (BL, WH, HH, RL, HW, CD, HG, and PBW) and two MQTs (UBT and ULA) for the five SNPs are presented in Tables 4, 5, and 6 .

In light of the information in Table 4, an association analysis of the polymorphisms with BMTs and MQTs at SNP1 revealed that the mean values of animals with the genotype GG were significantly higher than those with the genotype $\mathrm{AG}$ for $\mathrm{BL}, \mathrm{CD}$, and $\mathrm{HG}(\mathrm{P}<0.01)$. In addition, there were significant differences in RL and ULA between the two genotypes $(P<0.05)$. No association was found between any genotype and the other traits. Therefore, we believe that the missense mutation at the SNP1 locus may affect BMTs and MQTs in cattle, and could be used for MAS.

\begin{tabular}{|c|c|c|c|}
\hline \multirow[t]{2}{*}{ Trait (means $\pm \mathrm{SE}$ ) } & & \multicolumn{2}{|c|}{ Genotype } \\
\hline & & GG & $\mathrm{AG}$ \\
\hline \multirow{8}{*}{ Body measurement trait } & $\mathrm{BL}(\mathrm{cm})$ & $134.445 \pm 0.752^{\mathrm{A}}$ & $130.111 \pm 1.264^{\mathrm{B}}$ \\
\hline & WH $(\mathrm{cm})$ & $120.916 \pm 0.484$ & $120.311 \pm 1.076$ \\
\hline & $\mathrm{HH}(\mathrm{cm})$ & $123.603 \pm 0.428$ & $123.000 \pm 0.950$ \\
\hline & $\mathrm{RL}(\mathrm{cm})$ & $42.206 \pm 0.245^{\mathrm{a}}$ & $41.028 \pm 0.561^{b}$ \\
\hline & $\mathrm{HW}(\mathrm{cm})$ & $38.837 \pm 0.339$ & $38.931 \pm 0.648$ \\
\hline & $\mathrm{CD}(\mathrm{cm})$ & $59.291 \pm 0.415^{\mathrm{A}}$ & $56.729 \pm 0.797^{\mathrm{B}}$ \\
\hline & $\mathrm{HG}(\mathrm{cm})$ & $164.131 \pm 1.028^{\mathrm{A}}$ & $158.069 \pm 1.971^{\mathrm{B}}$ \\
\hline & PBW (cm) & $18.553 \pm 0.183$ & $18.431 \pm 0.425$ \\
\hline \multirow[t]{2}{*}{ Meat quality trait } & UBT $(\mathrm{cm})$ & $0.920 \pm 0.021$ & $0.873 \pm 0.038$ \\
\hline & ULA $\left(\mathrm{cm}^{2}\right)$ & $47.609 \pm 0.960^{\mathrm{a}}$ & $42.531 \pm 1.802^{\mathrm{b}}$ \\
\hline
\end{tabular}

$\overline{\mathrm{a}, \mathrm{b}}$ Means with different superscripts were significantly different $(\mathrm{P}<0.05) .{ }^{\mathrm{A}, \mathrm{B}}$ Means with different superscripts were significantly different $(\mathrm{P}<0.01) . \mathrm{SE}=$ standard error.

At the SNP2 locus (Table 5), there were highly significant differences between the CT and $\mathrm{CC}$ genotypes with $\mathrm{CD}, \mathrm{HG}, \mathrm{UBT}$, and ULA, and between the CT and TT genotypes with $\mathrm{CD}(\mathrm{P}<0.01)$. Individuals with the $\mathrm{CT}$ genotype had significantly higher mean values than those with the TT genotype for BL, WH, HW, HG, PBW, and ULA $(\mathrm{P}<0.05)$. In most cases, the $\mathrm{CT}$ genotype had the highest mean value, and may be the most beneficial genotype.

\begin{tabular}{|c|c|c|c|c|}
\hline \multirow[t]{2}{*}{ Trait (means $\pm \mathrm{SE}$ ) } & & \multicolumn{3}{|c|}{ Genotype } \\
\hline & & $\mathrm{CC}$ & CT & TT \\
\hline \multirow[t]{8}{*}{ Body measurement trait } & $\mathrm{BL}(\mathrm{cm})$ & $133.098 \pm 0.884$ & $135.007 \pm 1.089^{\mathrm{a}}$ & $129.933 \pm 2.177^{b}$ \\
\hline & WH $(\mathrm{cm})$ & $120.316 \pm 0.590$ & $122.033 \pm 0.752^{\mathrm{a}}$ & $118.167 \pm 1.295^{\mathrm{b}}$ \\
\hline & $\mathrm{HH}(\mathrm{cm})$ & $123.319 \pm 0.515$ & $124.151 \pm 0.662$ & $121.450 \pm 1.363$ \\
\hline & $\mathrm{RL}(\mathrm{cm})$ & $41.782 \pm 0.309$ & $42.478 \pm 0.381$ & $40.800 \pm 0.611$ \\
\hline & $\mathrm{HW}(\mathrm{cm})$ & $38.745 \pm 0.398$ & $39.493 \pm 0.511^{\mathrm{a}}$ & $36.667 \pm 0.873^{b}$ \\
\hline & $\mathrm{CD}(\mathrm{cm})$ & $58.122 \pm 0.462^{\mathrm{A}}$ & $60.180 \pm 0.672^{\mathrm{B}}$ & $56.433 \pm 1.050^{\mathrm{A}}$ \\
\hline & $\mathrm{HG}(\mathrm{cm})$ & $161.144 \pm 1.204^{\mathrm{A}}$ & $166.353 \pm 1.553^{\mathrm{aB}}$ & $158.233 \pm 2.961^{b}$ \\
\hline & PBW (cm) & $18.442 \pm 0.229$ & $18.890 \pm 0.276^{\mathrm{a}}$ & $17.433 \pm 0.556^{\mathrm{b}}$ \\
\hline \multirow[t]{2}{*}{ Meat quality trait } & UBT $(\mathrm{cm})$ & $0.874 \pm 0.024^{\mathrm{A}}$ & $0.976 \pm 0.033^{\mathrm{B}}$ & $0.845 \pm 0.030$ \\
\hline & $\operatorname{ULA}\left(\mathrm{cm}^{2}\right)$ & $44.875 \pm 1.120^{\mathrm{A}}$ & $49.969 \pm 1.460^{\mathrm{aB}}$ & $41.856 \pm 2.396^{\mathrm{b}}$ \\
\hline
\end{tabular}


The results of an association analysis between the polymorphisms in the CIDEC 3'-UTR and the BMTs and MQTs are presented in Table 6. HG, UBT, and ULA were significantly different between CT-AG-GA and CC-AA-GG $(\mathrm{P}<0.01)$, and individuals with the CTAG-GA genotype had significantly higher mean values for $\mathrm{HW}$ and $\mathrm{CD}(\mathrm{P}<0.05)$. Therefore, the CT-AG-GA genotype could be a valuable molecular marker for selecting desired BMTs and MQTs in Qinchuan cattle.

\begin{tabular}{|c|c|c|c|}
\hline \multirow[t]{2}{*}{ Trait (means $\pm \mathrm{SE}$ ) } & & \multicolumn{2}{|c|}{ Genotype } \\
\hline & & CC-AA-GG & CT-AG-GA \\
\hline \multirow[t]{8}{*}{ Body measurement trait } & $\mathrm{BL}(\mathrm{cm})$ & $133.137 \pm 0.708$ & $136.651 \pm 1.711$ \\
\hline & WH $(\mathrm{cm})$ & $120.545 \pm 0.477$ & $122.593 \pm 1.159$ \\
\hline & $\mathrm{HH}(\mathrm{cm})$ & $123.220 \pm 0.425$ & $125.361 \pm 0.936$ \\
\hline & $\mathrm{RL}(\mathrm{cm})$ & $41.830 \pm 0.246$ & $42.954 \pm 0.555$ \\
\hline & $\mathrm{HW}(\mathrm{cm})$ & $38.624 \pm 0.327^{\mathrm{a}}$ & $40.535 \pm 0.668^{b}$ \\
\hline & $\mathrm{CD}(\mathrm{cm})$ & $58.478 \pm 0.398^{\mathrm{a}}$ & $60.884 \pm 0.985^{b}$ \\
\hline & $\mathrm{HG}(\mathrm{cm})$ & $161.933 \pm 0.982^{\mathrm{A}}$ & $169.884 \pm 2.400^{\mathrm{B}}$ \\
\hline & PBW $(\mathrm{cm})$ & $18.437 \pm 0.183$ & $19.186 \pm 0.433$ \\
\hline \multirow{2}{*}{ Meat quality trait } & $\mathrm{UBT}(\mathrm{cm})$ & $0.892 \pm 0.019^{\mathrm{A}}$ & $1.042 \pm 0.059^{\mathrm{B}}$ \\
\hline & ULA $\left(\mathrm{cm}^{2}\right)$ & $45.688 \pm 0.896^{\mathrm{A}}$ & $53.001 \pm 2.534^{\mathrm{B}}$ \\
\hline
\end{tabular}

${ }_{\mathrm{a}, \mathrm{b}}$ Means with different superscripts were significantly different $(\mathrm{P}<0.05) .{ }^{\mathrm{A}, \mathrm{B}}$ Means with different superscripts were significantly different $(\mathrm{P}<0.01)$. For abbreviations, see Table 5.

\section{DISCUSSION}

With the development of molecular breeding technology in recent years, MAS has become an effective way for breeders to mark and identify quantitative trait loci (QTLs) in order to improve domestic animals' economically important traits and breeding efficiency (Wu et al., 2005). Candidate genes are crucial tools for investigating and localizing target genes that affect quantitative traits, by determining the relative magnitudes of polymorphic effects (Rothschild and Soller, 1997). Previous studies have followed the candidate gene approach with respect to milk production (Zhou and Dong, 2012), growth (Zhang et al., 2013), physiological processes (Wang et al., 2013), and meat quality (Liu et al., 2012; Fu et al., 2013).

The CIDEC gene plays important roles in regulating energy availability (Magnusson et al., 2008), lipid metabolism (Kim et al., 2008; Li et al., 2010), and the body mass index (Hall et al., 2010), and its polymorphisms may be used to investigate human partial lipodystrophy and 'ketosis-prone' insulin-resistant diabetes (Rubio-Cabezas et al., 2009). The present study provides evidence that CIDEC may also influence BMTs and MQTs. We found five CIDEC SNPs in this study, and associations between these and eight BMTs (BL, WH, HH, RL, HW, $\mathrm{CD}, \mathrm{HG}$, and PBW) and two BMTs (UBT and ULA) were analyzed in 531 Qinchuan cattle.

SNP1 was a missense mutation that resulted in a change from arginine to glutamine, and exhibited GG and AG genotypes. SNP2 was a synonymous mutation, and exhibited CC, $\mathrm{CT}$, and TT genotypes. Importantly, SNP3, 4, and 5 were completely linked, and only exhibited two genotypes (CC-AA-GG and CT-AG-GA). The absence of a third genotype at the SNP1 and SNP3-SNP4-SNP5 mutations may be because a third genotype does not exist in Qinchuan cattle, or because the sample size was too small. SNP3, 4, and 5 were in complete linkage disequilibrium, which may have been related to the short distances between them. 
SNP1 was associated with BL, RL, CD, HG, and ULA, and the GG genotype appeared to be the most beneficial genotype; the replacement of arginine with glutamine may affect the function of the protein produced by CIDEC. SNP2 was associated with BL, WH, HW, CD, HG, PBW, UBT, and ULA, and the CT genotype was the most beneficial. This synonymous mutation may indirectly affect messenger RNA splicing, stability, structure, as well as protein folding. These changes might have a significant effect on altering the structure, function, or expression levels of proteins (Hunt et al., 2009). SNP3-SNP4-SNP5 was associated with HW, CD, HG, UBT, and ULA, and the CT-AG-GA genotype was the most beneficial. The 3'-UTR is known to play crucial roles in the post-transcriptional regulation of gene expression, including nucleocytoplasmic transport (Köhler and Hurt, 2007), stability (Borrmann et al., 2001; Kamiyama et al., 2007), translation efficiency (Kindler et al., 2005; Piccone et al., 2009), and subcellular localization (Narsai et al., 2007; Thomsen et al., 2010). In addition, the binding sequence of the molecular regulator miRNA is usually located in the 3'-UTR (Grillo et al., 2010). Therefore, mutations in the 3'-UTR of the CIDEC gene might modulate the gene's expression levels, through a mechanism that is yet to be discovered.

In conclusion, based on the results obtained in this study, it can be inferred that $C I D E C$ mutations affect the BMTs and MQTs of Qinchuan cattle. Further studies should be conducted that investigate the mechanism involved, and the significance of the polymorphisms to BMTs and MQTs of cattle in different populations, and with larger sample sizes.

\section{Conflicts of interest}

The authors declare no conflict of interest.

\section{ACKNOWLEDGMENTS}

We thank all of the research assistants and laboratory technicians who contributed to this study. Research supported by the National Science and Technology Support Projects (\#2011BAD28B04-03), the Natural Science Foundation of China (\#31272411), the National "863" Projects of China (\#2013AA102505 and \#2011AA100307-02), and the Technology System Special Construction Foundation of National Modern Agriculture Industry of China (CARS-38).

\section{REFERENCES}

Borrmann L, Wilkening S and Bullerdiek J (2001). The expression of HMGA genes is regulated by their 3'UTR. Oncogene 20: 4537-4541.

Brethour JR (1994). Estimating marbling score in live cattle from ultrasound images using pattern recognition and neural network procedures. J. Anim. Sci. 72: 1425-1432.

Danesch U, Hoeck W and Ringold GM (1992). Cloning and transcriptional regulation of a novel adipocyte-specific gene, FSP27. CAAT-enhancer-binding protein (C/EBP) and C/EBP-like proteins interact with sequences required for differentiation-dependent expression. J. Biol. Chem. 267: 7185-7193.

Fu CZ, Wang H, Mei CG, Wang JL, et al. (2013). SNPs at 3'-UTR of the bovine CDIPT gene associated with Qinchuan cattle meat quality traits. Genet. Mol. Res. 12: 775-782.

Gilbert RP, Bailey DR and Shannon NH (1993). Linear body measurements of cattle before and after 20 years of selection for postweaning gain when fed two different diets. J. Anim. Sci. 71: 1712-1720.

Grillo G, Turi A, Licciulli F, Mignone F, et al. (2010). UTR db and UTR site (RELEASE 2010): a collection of sequences and regulatory motifs of the untranslated regions of eukaryotic mRNAs. Nucleic Acids Res. 38: D75-D80.

Hall AM, Brunt EM, Klein S and Finck BN (2010). Hepatic expression of cell death-inducing DFFA-like effector C in obese subjects is reduced by marked weight loss. Obesity 18: 417-419. 
Hamlin KE, Green RD, Cundiff LV, Wheeler TL, et al. (1995). Real-time ultrasonic measurement of fat thickness and longissimus muscle area: II. Relationship between real-time ultrasound measures and carcass retail yield. J. Anim. Sci. 73: 1725-1734.

Hunt R, Sauna ZE, Ambudkar SV, Gottesman MM, et al. (2009). Silent (synonymous) SNPs: should we care about them? In: Single nucleotide polymorphisms: methods and protocols (Kwok P-Y, ed.). Humana Press, New York, 23-39.

Inohara N, Koseki T, Chen S, Wu X, et al. (1998). CIDE, a novel family of cell death activators with homology to the 45 $\mathrm{kDa}$ subunit of the DNA fragmentation factor. EMBO J. 17: 2526-2533.

Kamiyama M, Kobayashi M, Araki SI, Iida A, et al. (2007). Polymorphisms in the 3' UTR in the neurocalcin $\delta$ gene affect mRNA stability, and confer susceptibility to diabetic nephropathy. Hum. Genet. 122: 397-407.

Keller P, Petrie JT, De Rose P, Gerin I, et al. (2008). Fat-specific protein 27 regulates storage of triacylglycerol. J. Biol. Chem. 283: 14355-14365.

Kim YJ, Cho SY, Yun CH, Moon YS, et al. (2008) Transcriptional activation of Cidec by PPAR gamma2 in adipocyte. Biochem. Biophys. Res. Commun. 377: 297-302.

Kindler S, Wang H, Richter D and Tiedge H (2005). RNA transport and local control of translation. Annu. Rev. Cell Dev. Biol. 21: 223.

Köhler A and Hurt E (2007). Exporting RNA from the nucleus to the cytoplasm. Nat. Rev. Mol. Cell Biol. 8: 761-773.

Li F, Gu Y, Dong W, Li H, et al. (2010). Cell death-inducing DFF45-like effector, a lipid droplet-associated protein, might be involved in the differentiation of human adipocytes. FEBS J. 277: 4173-4183.

Liang L, Zhao M, Xu Z, Yokoyama K, et al. (2003). Molecular cloning and characterization of CIDE-3, a novel member of the cell-death-inducing DNA-fragmentation-factor (DFF45)-like effector family. Biochem. J. 370: 195-203.

Liu X, Guo XY, Xu XZ, Wu M, et al. (2012). Novel single nucleotide polymorphisms of the bovine methyltransferase 3b gene and their association with meat quality traits in beef cattle. Genet. Mol. Res. 11: 2569-2577.

Magnusson B, Gummesson A, Glad CA, Goedecke JH, et al. (2008). Cell death-inducing DFF45-like effector C is reduced by caloric restriction and regulates adipocyte lipid metabolism. Metabolism 57: 1307-1313.

Müllenbach R, Lagoda PJ and Welter C (1989). An efficient salt-chloroform extraction of DNA from blood and tissues. Trends Genet. 5: 391-391.

Narsai R, Howell KA, Millar AH, O’Toole N, et al. (2007). Genome-wide analysis of mRNA decay rates and their determinants in Arabidopsis thaliana. Plant Cell Online 19: 3418-3436.

Nei M and Roychoudhury AK (1974). Sampling variances of heterozygosity and genetic distance. Genetics 76: 379-390.

Nei M and Li WH (1979). Mathematical model for studying genetic variation in terms of restriction endonucleases. Proc. Natl. Acad. Sci. U. S. A. 76: 5269-5273.

Nishino N, Tamori Y, Tateya S, Kawaguchi T, et al. (2008). FSP27 contributes to efficient energy storage in murine white adipocytes by promoting the formation of unilocular lipid droplets. J. Clin. Invest. 118: 2808.

Nkrumah JD, Li C, Basarab JB, Guercio S, et al. (2004). Association of a single nucleotide polymorphism in the bovine leptin gene with feed intake, feed efficiency, growth, feeding behaviour, carcass quality and body composition. Can. J. Anim. Sci. 84: 211-219.

Piccone ME, Pauszek S, Pacheco J, Rieder E, et al. (2009). Molecular characterization of a foot-and-mouth disease virus containing a 57-nucleotide insertion in the 3' untranslated region. Arch. Virol. 154: 671-676.

Puri V, Konda S, Ranjit S, Aouadi M, et al. (2007). Fat-specific protein 27, a novel lipid droplet protein that enhances triglyceride storage. J. Biol. Chem. 282: 34213-34218.

Rothschild MF and Soller M (1997). Candidate gene analysis to detect genes controlling traits of economic importance in domestic livestock. Probe 8: 13-20.

Rubio-Cabezas O, Puri V, Murano I, Saudek V, et al. (2009). Partial lipodystrophy and insulin resistant diabetes in a patient with a homozygous nonsense mutation in CIDEC. EMBO Mol. Med. 1: 280-287.

Thomsen S, Anders S, Janga SC, Huber W, et al. (2010). Genome-wide analysis of mRNA decay patterns during early Drosophila development. Genome Biol. 11: R93.

Toh SY, Gong J, Du G, Li JZ, et al. (2008). Up-regulation of mitochondrial activity and acquirement of brown adipose tissue-like property in the white adipose tissue of fsp27 deficient mice. PLoS One 3: e2890.

Wang W, Tao C, Zhou P, Zhou X, et al. (2013). Molecular characterization, expression profiles of the porcine SDC2 and HSPG2 genes and their association with hematologic parameters. Mol. Biol. Rep. 40: 2549-2556.

Wu XL, Macneil MD, De S, Xiao QJ, et al. (2005). Evaluation of candidate gene effects for beef backfat via Bayesian model selection. Genetica 125: 103-113.

Zhang ZJ, Ling YH, Wang LJ, Hang YF, et al. (2013). Polymorphisms of the myostatin gene (MSTN) and its relationship with growth traits in goat breeds. Genet. Mol. Res. 12: 965.

Zhou JP and Dong CH (2012). Association between a polymorphism of the $\alpha$-lactalbumin gene and milk production traits in Chinese Holstein cows. Genet. Mol. Res. 12: 3375-3382. 